\title{
Identification of chromosomes involved in a Robertsonian translocation in cattle
}

\author{
E.P. Cribiu ${ }^{1}$, M. Matejka ${ }^{2}$, R. Darre ${ }^{2}$, V. Durand ${ }^{1}$, H.M. Berland ${ }^{2}$ and \\ A. Bouvet ${ }^{1}$ \\ 1 Institut National de la Recherche Agronomique, laboratoire de cytogénétique, centre de \\ recherches de Jouy-en-Josas, 78350 Jouy-en-Josas; \\ 2 Ecole Nationale Vétérinaire de Toulouse, laboratoire de cytogénétique, 23, chemin des \\ Capelles, 31076 Toulouse Cédex, France
}

(received 29 June 1989; accepted 30 August 1989)

Summary - The chromosomes involved in the robertsonian translocation described after classical Giemsa staining by Darre et al. (1974), were determined using G(GTG), $R(R B A)$ and $C(C B G)$ banding techniques. The chromosomes in question were identified as chromosomes 9 and 23.

cattle - chromosome - robertsonian translocation

Résumé - Les chromosomes impliqués dans une translocation robertsonienne décrite, tout d'abord, en coloration conventionnelle par Darre et al. (1974) ont été déterminés à l'aide des techniques de marquage $G(G T G), R(R B A)$ et $C(C B G)$. Les chromosomes concernés sont le 9 et le 23.

bœuf - chromosome - translocation robertsonienne

\section{INTRODUCTION}

In the field of animal cytogenetics, cattle are the most extensively studied livestock species with about 20000 karyotyped animals. Chromosomal abnormalities reported in cattle usually involve robertsonian translocations, among which the most widespread is the $1 / 29$ translocation observed for the first time by Gustavsson and Rockborn (1964) in the Swedish Red and White cattle and reported later in various breeds worldwide (Popescu, 1977). Robertsonian translocations involving other autosomes have also been reported (Berland et al., 1988). However, in contrast to the $1 / 29$ translocation, the other translocations have been reported only as isolated cases and for those described during the early seventies prior to the development of reliable banding methods, the chromosomes involved have not been identified precisely. For example, in 1974 a robertsonian translocation, the socalled "F translocation", was reported in a Blonde d'Aquitaine bull without clear identification of the chromosomes involved. Based on chromosomal measurements only, it was suggested that the 2 chromosomes involved belong to the chromosome groups 7 to 11 and 20 to 25, respectively (Darre et al., 1974). In this report, the 
chromosomes involved in the translocation were identified using the $\mathrm{G}, \mathrm{C}$ and $\mathrm{R}$ banding methods.

\section{MATERIALS AND METHODS}

\section{Animals}

A total of 16 cows were inseminated with frozen semen from F..., a Blonde d'Aquitaine A.I bull carrying two translocations (Darre et al., 1974). The karyotype of the 13 calves produced was studied using blood and tissue cultures.

\section{Methods}

Venous blood samples were collected aseptically from the jugular or the caudal vein, using sterile vacutainer tubes coated with sodium heparin. Whole blood (10 drops) was added to the culture medium containing $9 \mathrm{ml}$ of Ham's F12 growth medium, $20 \%$ of fetal calf serum, $25 \mu \mathrm{g} / \mathrm{ml}$ of concanavalin A and various antibiotics. The cultures were incubated at $37^{\circ} \mathrm{C}$ for $68 \mathrm{~h}$. Colcemid $(0.03 \mu \mathrm{g} / \mathrm{ml}$ : final concentration) was added 90 min prior to harvest. After a 10 min hypotonic treatment with potassium chloride $(0.56 \%)$ and 3,1 -h fixations in modified Carnoy's solution (3:1 absolute ethanol: glacial acetic acid), resuspended cells were spread on glass slides, flame-dried, and either stored unstained at room temperature, or stained for 10 min with a $4 \%$ Giemsa solution.

Chromosomal analysis was also performed on primary cell cultures established from small dilacerated testicular fragments digested in $2.5 \mathrm{~g} / \mathrm{l}$ trypsin solution.

Unstained slides were treated for G banding (GTG) using the method of Seabright (1971) and C banding (CBG) following the method of Sumner (1972). For $\mathrm{R}$ banding (RBA), 5-bromodeoxyuridine (BrdU, $20 \mu \mathrm{g} / \mathrm{ml}$ ) was added to some cultures $8 \mathrm{~h}$ before harvesting. The slides were stained with acridine orange (Dutrillaux et al., 1973) and observed under UV light using a Leitz microscope.

The chromosomes were identified, paired and arranged according to the recommendations of the 1976 Reading conference (Ford et al., 1980).

\section{RESULTS}

Out of 16 cows inseminated with F... semen, 13 carried to term, 8 males and 5 females. Among the males: 3 had a normal 60,XY karyotype, 4 were carriers of both the $F$ and the $1 / 29$ translocations, and 1 animal carried only the $F$ fusion. Out of 5 females, 1 carried the $F$ fusion, 2 were $1 / 29$ translocation carriers, and 2 carried both abnormalities. The G(GTG) and R(RBA) banding techniques made it possible to confirm the presence of the $1 / 29$ translocation and to identify the chromosomal pairs involved in the $\mathrm{F}$ fusion as pairs 9 and 23, respectively (Figs. 1 and 2).

The $\mathrm{C}$ banding technique revealed the presence of 2 constitutive heterochromatin blocks in the pericentromeric region of the $\mathrm{F}$ chromosome and only 1 block on the long arms near the centromere of the 1/29 translocated chromosome (Fig. 3). 


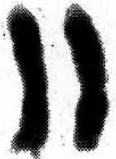

1

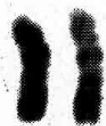

7

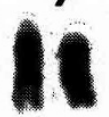

13

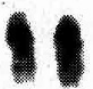

19

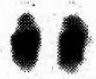

25

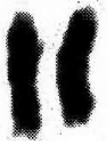

2

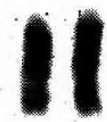

8

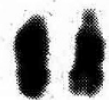

14

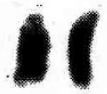

20

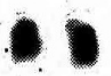

26

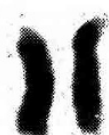

3

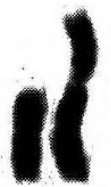

9 9/23

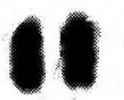

15

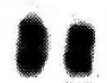

21

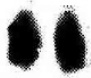

27

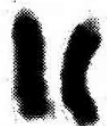

4

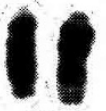

10

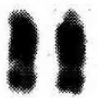

16

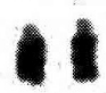

22

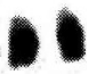

28

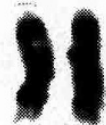

5

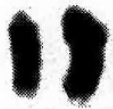

11

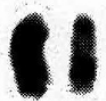

12
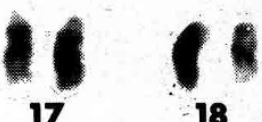

17

18
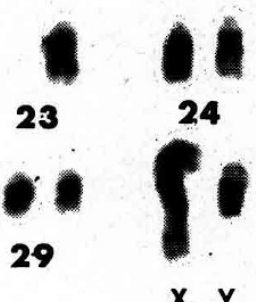

Fig. 1. GTG-banded karyotype with the $9 / 23$ translocation.

\section{DISCUSSION AND CONCLUSIONS}

The $9 / 23$ translocation is, to our knowledge, the third translocation reported in the Blonde d'Aquitaine breed, after the 1/29 translocation (Darre et al., 1972; Bruere and Chapman, 1973; Popescu, 1973) and the 21/27 translocation (Berland et al., 1988).

The 1/29 translocation is widespread in the Blonde d'Aquitaine breed, since the frequency of the hetero and homozygous carriers ranges from 14 to $24 \%$ (Queinnec et al., 1974; Cribiu, 1985; Frebling et al., 1987). In contrast, the 21/27 translocation like the $9 / 23$ has been observed only in 1 bull and its progeny (Darre et al., 1974; Berland et al., 1988).

Centric fusions or robertsonian translocations are the result from the fusion of 2 acrocentric chromosomes. At least 2 types of robertsonian translocations have been described, depending on the presence of 1 or 2 blocks of constitutive heterochromatin. In the first case, 1 of the chromosomal breakpoints involves the short arms of 1 chromosome and the other is on the long arms of the second chromosome near the centromeric regions. The fusion gives rise to a monocentric meta or submetacentric chromosome and a minute fragment containing the centromere, which is lost during the subsequent cell divisions. On the other hand, if the breakpoints involve only the short arms of both chromosomes in 


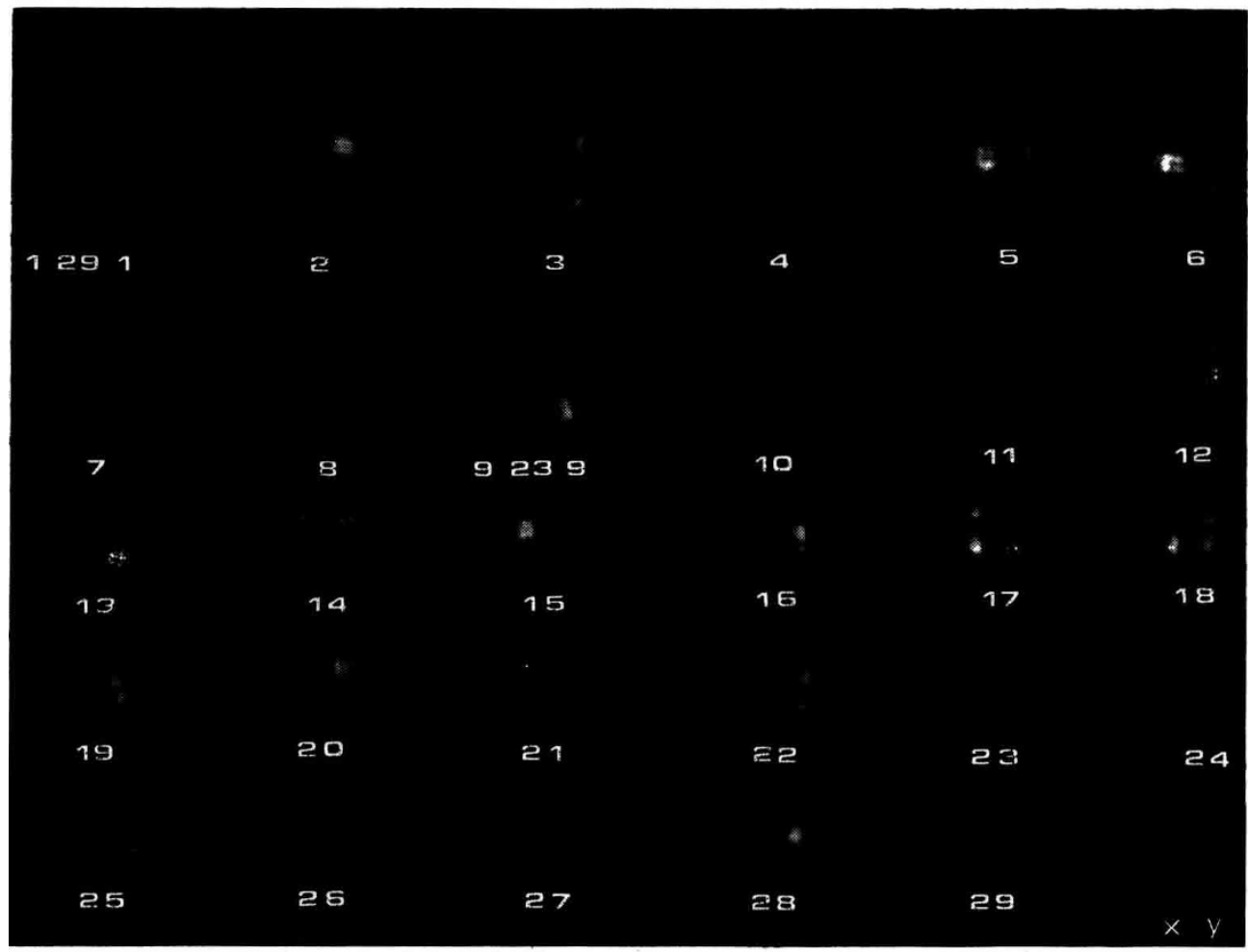

Fig. 2. RBA-banded karyotype with both $1 / 29$ and $9 / 23$ translocations.

the centromeric region, fusion leads to the formation of a dicentric meta or submetacentric chromosome and the loss of 2 acentric fragments.

The use of the $\mathrm{C}$ banding technique made it possible to suggest the mechanism by which these 2 translocations arise: the $1 / 29$ chromosome with only 1 constitutive heterochromatin block on the long arms near the centromere could be monocentric (Popescu, 1973; Gustavsson et al., 1976), whereas the 9/23 chromosome with 2 constitutive heterochromatin blocks in the pericentromeric region could be dicentric.

According to most authors, dicentric translocations like those already described in cattle are more recent than those which are monocentric like the $1 / 29$ translocation (Eldridge, 1974; Popescu, 1977; Logue and Harvey, 1978; Di Berardino et al., 1979; Ellsworth et al., 1979; Berland et al. 1988).

Chromosomal abnormalities associated with morphological defects are rapidly eliminated through selective breeding and do not constitute an important economic drain for the livestock industry. In contrast, animals carrying structural abnormalities like robertsonian translocations do not alter the phenotype, but their fertility is impaired since meiotic segregation leads to unbalanced gametes. Those rearrangements are not easily eliminated by selective breeding and can be spread rapidly through the use of artificial insemination. For example, in cattle, the $1 / 29$ translo- 
cation which does not confer any advantage to heterozygous carriers, produces in certain breeds a reduced fertility in the daughters of carrier bulls (Gustavsson, 1969; Refsdal, 1976).

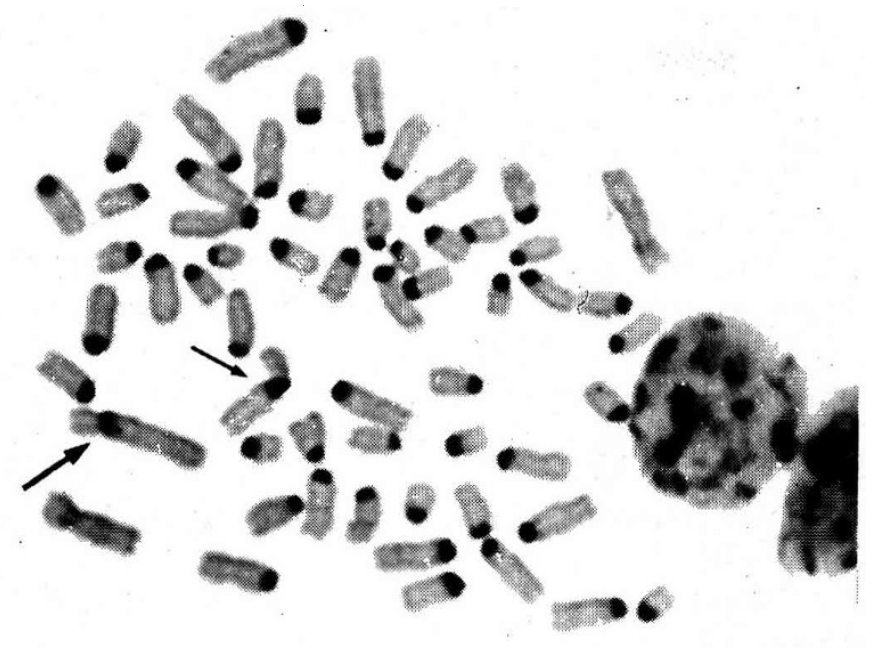

Fig. 3. CBG-banded metaphase showing constitutive heterochromatin as one block in the $1 / 29$ translocation (large arrow) and two blocks in the $9 / 23$ translocation (small arrow).

\section{ACKNOWLEDGMENTS}

The help of Mr G. Fabre and his technical staff in the housing and handling of the animals at the Domaine Experimental de Carmaux (INRA) is gratefully acknowledged.

\section{REFERENCES}

Berland H.M., Sharma A., Cribiu E.P., Darre R., Boscher J. \& Popescu C.P. (1988) A new case of robertsonian translocation in cattle. J. Hered. 79, 33-36

Bruere A.N. \& Chapman H.M. (1973) Autosomal translocations in two exotic breeds of cattle in New Zealand. Vet. Rec. 92, 615-620

Cribiu E.P. (1985) Fréquence de la translocation 1/29 dans les centres d'insémination artificielle français. Elev. Insémin. 209, 17-22

Darre R., Berland H.M. \& Queinnec G. (1974) Une nouvelle translocation robertsonienne chez les bovins. Ann. Génét. Sél. Anim. 6, 297-303

Darre R., Queinnec G. \& Berland H.M. (1972) La translocation 1/29 des bovins. Etude générale et importance du phénomène dans le Sud-Ouest. Rev. Méd. Vét. $123,477-494$ 
Di Berardino D., Iannuzzi L., Farrara L. \& Matassino D. (1979) A new case of robertsonian translocation in cattle. J. Hered. 70, 436-438

Dutrillaux B., Laurent C., Couturier J. \& Lejeune J. (1973) Coloration des chromosomes humains par l'acridine orange, après traitement par le 5-bromodeoxyuridine. C.R. Acad. Sci. 276, 3179-3182

Eldridge F.E.A. (1974) A dicentric robertsonian translocation in a Dexter cow. $J$. Hered. 65, 353-355

Ellsworth S.M., Paul R.S. \& Bunch T.D. (1979) A 14/28 dicentric robertsonian translocation in a Holstein cow. Theriogenology 11, 165-171

Ford C.E., Pollock D.L. \& Gustavsson I. (1980) Proc. 1st Int. Conf. Standardization of Banded Karyotypes of Domestic Animals, Reading, 2-6 August 1976. Hereditas $92,145-162$

Frebling J., Foulley J.L., Berland H.M., Popescu C.P., Cribiu E.P. \& Darre R. (1987) Résultats de l'enquête sur la fréquence de la translocation $1 / 29$ en race bovine Blonde d'Aquitaine. Bull. Tech. C.R.Z.V. Theix, INRA 67, 49-58

Gustavsson I. (1969) Cytogenetics, distribution and phenotypic effects of a translocation in Swedish cattle. Hereditas 63, 68-169

Gustavsson I. \& Rockborn G. (1964) Chromosome abnormality in 3 cases of lymphatic leukaemia. Nature 203, 990

Gustavsson I., Hageltorn M. \& Zech L. (1976) Identification of the 1/29 translocation in the Swedish Red and White (SRB) cattle breed by utilization of new staining techniques. Hereditas $82,260-262$

Logue D.N. \& Harvey M.J.A. (1978) A 14/20 robertsonian translocation in Swiss Simmental cattle. Res. Vet. Sci. 25, 7-12

Popescu C.P. (1973) L'hétérochromatine constitutive dans le caryotype bovin normal et anormal. Ann. Génét. 16, 183-188

Popescu C.P. (1973) Nouvelles observations sur une fusion centrique chez Bos taurus L. Ann. Génét. Sél. Anim. 5, 435-440

Popescu C.P. (1977) Les anomalies chromosomiques des bovins (Bos taurus L.). Etat actuel des connaissances. Ann. Génét. Sél. Anim. 9, 463-470

Popescu C.P. (1977) A new type of robertsonian translocation in cattle. J. Hered. $68,138-142$

Queinnec C., Darre R., Berland H.M. \& Raynaud J.C. (1974) Etude de la translocation 1/29 dans la population bovine du Sud-Ouest de la France: Conséquences zootechniques. Prem. Congr. Mond. Génét. Appl. Elev., 7-11 octobre 1974, Madrid, Editorial Garsi, Spain, pp. 131-151

Refsdal A.O. (1976) Low fertility in daughters of bulls with $1 / 29$ translocation. Acta Vet. Scand. 17, 190-195

Seabright M. (1971) A rapid banding technique for human chromosomes. Lancet 2, 971-972

Sumner A.T. (1972) A simple technique for demonstrating centromeric heterochromatin. Exp. Cell Res. 75, 304-306 